DOI: https://doi.org/10.24127/ajpm.v10i2.3372

\title{
KEMAMPUAN PENALARAN ADAPTIF DALAM MENYELESAIKAN SOAL LOGIKA MATEMATIKA BERDASARKAN KREATIVITAS BELAJAR
}

\author{
Rahman Haryadi $^{1}$, Dwi Oktaviana ${ }^{2^{*}}$ \\ ${ }^{1,2}$ Pendidikan Matematika IKIP PGRI Pontianak, Pontianak, Indonesia \\ * Jl. Ampera No. 88, 78116, Pontianak, Indonesia \\ E-mail: rahmanharyadi72@gmail.com ${ }^{1)}$ \\ dwi.oktaviana7@gmail.com ${ }^{2 *}$
}

Received 09 December 2020; Received in revised form 16 March 2021; Accepted 05 April 2021

\begin{abstract}
Abstrak
Tujuan dari penelitian ini adalah untuk menganalisis kemampuan penalaran adaptif dalam menyelesaikan soal logika matematika berdasarkan kreativitas belajar mahasiswa. Jenis penelitian ini menggunakan penelitian kualitatif dengan bentuk studi kasus. Subjek penelitian adalah mahasiswa kelas B semester I IKIP PGRI Pontianak dimana diambil satu mahasiswa untuk kreativitas belajar tinggi, kreativitas belajar sedang, dan kreativitas belajar rendah. Subjek dipilih dengan menggunakan teknik purposive sampling. Teknik pengumpulan data yang digunakan adalah tes tertulis, teknik komunikasi tidak langsung, dan wawancara, sedangkan instrumen pada penelitian ini adalah soal tes penalaran adaptif, angket kreativitas belajar, dan pedoman wawancara. Untuk menguji keabsahan data digunakan triangulasi teknik. Analisis data dilakukan dengan reduksi data, penyajian data, dan penarikan kesimpulan. Hasil dari penelitian diperoleh bahwa mahasiswa dengan kreativitas belajar tinggi mememenuhi empat indikator yaitu menyusun dugaan, memeberikan alasan terhadap kebenaran suatu pernyataan, menarik kesimpulan dari suatu pernyataan, dan memeriksa kesahihan suatu argumen namun belum memenuhi indikator menemukan pola dari gejala matematis, mahasiswa dengan kreativitas belajar sedang hanya memenuhi dua indikator yaitu menyusun dugaan dan memeriksa kesahihan suatu argumen dan Mahasiswa dengan kreativitas belajar rendah hanya memenuhi satu indikator yaitu memberikan alasan atau bukti terhadap suatu pernyataan.
\end{abstract}

Kata Kunci: Kemampuan penalaran adaptif; kreativitas belajar; logika matematika.

\begin{abstract}
The purpose of this study was to analyze adaptive reasoning skills in solving mathematical logic problems based on student learning creativity. This type of research uses qualitative research with a case study form. The research subjects were students of class B semester I IKIP PGRI Pontianak where one students were taken for high learning creativity, moderate learning creativity, and low learning creativity. Subjects were chosen using purposive sampling technique. The data collection techniques used were written tests, indirect communication techniques, and interviews, while the instruments in this study were adaptive reasoning test questions, learning creativity questionnaires, and interview guidelines. To test the validity of data used triangulation technique. Data analysis was conducted through sata reduction, data presentation and conclusion. The results of the study show that students with high learning creativity fulfill four indicators, namely formulating assumptions, giving reasons for the truth of a statement, drawing conclusions from a statement, and checking the validity of an argument but not meeting the indicators of finding patterns of mathematical symptoms, students with moderete learning creativity onlt fulfills tro indicators, namely constructing assumptions and checking the validity of an argument and students with low learning creativity only fulfill one indicator, namely providing reasons or evidence for a statement.
\end{abstract}

Keywords: Adaptive reasoning ability; learning creativity; mathematical logic.

This is an open access article under the Creative Commons Attribution 4.0 International License 


\section{PENDAHULUAN}

Logika matematika merupakan salah satu materi yang tidak terlepas dari proses penalaran. Logika berkaitan dengan argumen-argumen (pernyataan), yang mempelajari metode-metode dan prinsip-prinsip untuk menunjukkan keabsahan (sah atau tidaknya) suatu argument, khusunya yang dikembangkan melalui penggunaan metode-metode matematika dan simbolsimbol matematika (Mirati, 2013; Novianti, 2015). Oleh karena itu, logika matematika berkaitan erat dengan penalaran.

National Council of Teachers of Mathematics menetapkan salah satu standar kemampuan matematis yang harus dimiliki adalah penalaran (Lestari \& Andinny, 2020; Putra \& Sari, 2016). Selain itu, (Bernard, 2015) berpendapat bahwa siswa dalam mempelajari matematika memerlukan penalaran untuk mencetuskan ide atau gagasannya dalam memecahkan masalah sehingga siswa dapat memahami konsep matematika yang benar. Selain itu, (Rosnawati, 2013) menyatakan kemampuan penalaran matematika merupakan syarat cukup untuk dapat menguasai matematika.

Kemampuan penalaran matematis diartikan sebagai suatu kemampuan yang dimiliki peserta didik dalam melakukan penarikan kesimpulan melalui langkah formal dalam bentuk analisis dan interpetasi permasalahan berdasarkan konsep serta melakukan pengujian kebenaran yang didasarkan dari hubungan sebab akibat suatu informasi yang diberikan (Herdiman, 2017; Kasmer \& Kim, 2011; Ponte, Mata-Pereira, \& Henriques, 2012; Zulkarnaen, 2017). Selain itu, penalaran merupakan cara berpikir siswa yang logis secara pendekatan induktif yaitu pembelajaran memberikan bukti yang logis untuk mencapai kesimpulan dan pembelajaran deduktif yaitu konsepkonsep penyelesaian masalah yang berdasarkan penguasaan ilmu yang telah terbukti sehingga siswa dapat berpikir secara logis berdasarkan fakta yang ada untuk menarik kesimpulan (Bernard, 2015).

Penalaran yang mencakup kemampuan induksi dan deduksi adaptif adalah penalaran adaptif (Kilpatrick \& Swafford, 2001). Penalaran adaptif merupakan kapasitas untuk berpikir secara logis tentang hubungan antar konsep dan situasi, kemampuan untuk berpikir reflektif, kemampuan untuk menjelaskan, dan kemampuan untuk memberikan pembenaran (Indriani, Hartoyo, \& Astuti, 2017; Putra \& Sari, 2016). (Widjajanti, 2011) mengemukakan penalaran adaptif didasarkan pada lima indikator yaitu 1) menyusun dugaan, 2) memberikan alasan atau bukti terhadap kebenaran suatu pernyataan, 3) menarik kesimpulan dari suatu pernyataan, 4) memeriksa kesahihan suatu argument, dan 5) menemukan pola pada gejala matematis.

Beberapa penelitian tentang kemampuan penalaran adaptif antara lain: 1) (Indriani et al., 2017) menyatakan bahwa kemampuan penalaran adaptif siswa masih rendah dan 2) (Afifian \& Setyaningsih, 2019) menyimpulkan bahwa siswa belum mampu dan menguasai sepenuhnya indikator dari kemampuan penalaran adaptif. Penelitian tersebut menunjukkan bahwa penalaran adaptif masih tergolong rendah.

Hal ini juga terjadi pada mahasiswa, ketika dilakukan pra observasi terdapat $37,04 \%$ mahasiswa yang mampu menyelesaikan soal penalaran adaptif sehingga masih tergolong rendah (Oktaviana \& 
Haryadi, 2020). Selain itu, berdasarkan pengamatan terhadap penyelesaian yang dilakukan mahasiswa diperoleh informasi bahwa mahasiswa dalam menjawab soal masih belum kreatif dalam menjawab soal dimana penyelesaian yang dilakukan masih berpatokan pada konsep jadi ketika dihadapkan dengan penyelesaian yang baru maka mahasiswa kesulitan. Oleh karena itu faktor kreativitas belajar juga mempengaruhi kemampuan mahasiswa.

Kreativitas merupakan faktor internal yang dimiliki oleh setiap mahasiswa dan sangat mempengaruhi dalam mencapai hasil belajar (Siagian \& Nurfitriyanti, 2015). Kreativitas adalah kemampuan seseorang untuk menghasilkan komposisi, produk atau gagasan apa saja yang pada dasarnya baru, dan sebelumnya tidak dikenal pembuatnya. Kreativitas mencerminkan dinamika seseorang untuk mampu melakukan sesuatu yang baru atau dengan cara baru (Budiarti \& Jabar, 2016).

Berdasarkan uraian sebelumnya maka penelitian ini bertujuan untuk menganalisis kemampuan penalaran adaptif mahasiswa dalam menyelesaikan soal logika matematika berdasarkan kreativitas belajar.

\section{METODE PENELITIAN}

Metode penelitian yang digunakan dalam penelitian ini adalah penelitian kualitatif. Bentuk penelitian yang digunakan adalah penelitian studi kasus. Penelitian ini dilakukan di Prodi Pendidikan Matematika IKIP PGRI Pontianak. Subjek dalam penelitian ini adalah mahasiswa kelas B semester I yang sedang mengikuti perkuliahan Logika Matematika dan Himpunan (LMH) dimana diambil satu mahasiswa dengan kreativitas belajar tinggi, sedang, dan rendah. Pengambilan dilakukan dengan menggunakan teknik purposive sampling.

Prosedur penelitian yang dilakukan antara lain: 1) memberikan angket kreativitas belajar kepada mahasiswa, 2) melakukan analisis data terkait angket untuk menentukan subjek penelitian, 3) memberikan tes kepada subjek penelitian, dan 4) melakukan wawancara kepada subjek penelitian.

Teknik pengumpul data yang digunakan dalam penelitian ini adalah tes tertulis, teknik komunikasi tidak langsung, dan wawancara. Tes tertulis digunakan untuk mengetahui kemampuan penalaran adaptif, teknik komunikasi tidak langsung digunakan untuk mengetahui kreativitas belajar mahasiswa, dan wawancara digunakan untuk menggali lebih dalam terhadap kemampuan penalaran adaptif mahasiswa. Instrumen dalam penelitian ini adalah soal tes terhadap kemampuan penalaran adaptif, angket kreativitas belajar, dan pedoman wawancara. Soal tes yang digunakan dalam penelitian ini adalah tes yang berbentuk soal uraian dimana memuat lima indikator dari kemampuan penalaran adaptif. Soal tes yang diujikan adalah soal tes yang terlebih dahulu dilakukan validasi isi, kemaudian direvisi sesuai dengan saran dari para validator. Setelah itu, soal tes diujicobakan terlebih dahulu untuk mengetahui tingkat kevalidan soal, tingkat kesukaran soal, daya pembeda soal serta kereliabelan soal untuk mendapatkan soal yang valid dan reliabel. Adapun soal yang diujicobakan terdapat 5 soal ketika diujicobakan kelima soal tersebut dapat digunakan untuk tes dan kelima soal memuat lima indikator dari kemampuan penalaran adaptif.

Teknik analisis data dalam penelitian ini adalah reduksi data, penyajian data, dan penarikan 
kesimpulan. Untuk menguji keabsahan data digunakan triangulasi teknik yaitu dengan membandingkan analisis kemampuan penalaran adaptif mahasiswa yang diperoleh dari jawaban subjek penelitian dengan hasil wawancara subjek penelitian.

\section{HASIL DAN PEMBAHASAN}

Berdasarkan angket kreativitas belajar, peneliti memilih 3 mahasiswa dari 27 mahasiswa yang telah diberi angket kreativitas belajar sebagai subjek penelitian. Adapun 3 mahasiswa yang akan dianalisis data tes kemampuan penalaran adaptif dan dilakukan wawancara diambil 1 orang dari setiap kategori kreativitas belajar. Mahasiswa yang terpilih sebagai subjek penelitian dapat dilihat pada Tabel 1 .

Tabel 1. Subjek penelitian

\begin{tabular}{cccc}
\hline No & Kode & Nilai & Kreativitas \\
\hline 1 & AS (S1) & 86,67 & Tinggi \\
2 & MGAK (S2) & 60 & Sedang \\
3 & OOS (S3) & 40 & Rendah \\
\hline
\end{tabular}

Selanjutnya akan dilakukan deskripsi dan analisis data tentang kemampuan penalaran adaptif mahasiswa dalam menyelesaikan soal logika matematika. Berikut disajikan soal tes tentang kemampuan penalaran adaptif pada Gambar 1.

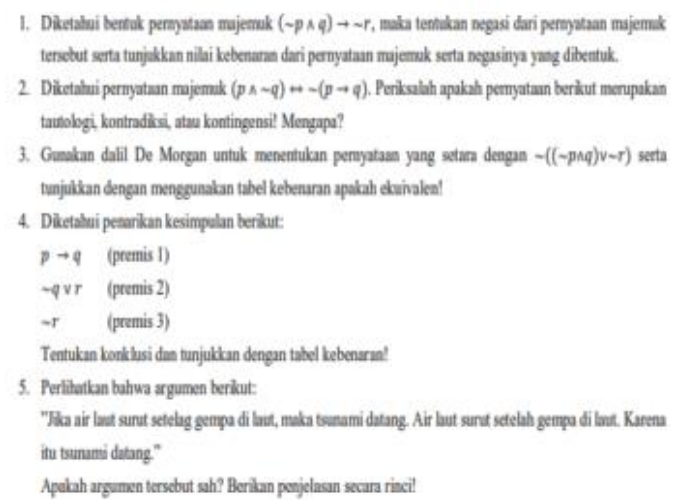

Gambar 1. Soal tes kemampuan penalaran adaptif
Dari soal yang diberikan memuat lima indikator dari penalaran adaptif dimana soal nomor 1 memuat indikator menemukan pola pada gejala matematis, soal nomor 2 memuat indikator menyusun dugaan, soal nomor 3 memuat indikator memberikan alasan atau bukti terhadap kebenaran suatu pernyataan, soal nomor 4 memuat indikator menarik kesimpulan dari suatu pernyataan, dan soal nomor 5 memuat indikator memeriksa kesahihan suatu argumen. Berikut deskripsi kemampuan penalaran mahasiswa dalam menyelesaikan soal logika matematika.

\section{Deskripsi Hasil Tes Tertulis pada S1}

Hasil pekerjaan S1 untuk soal nomor 1 dapat dilihat pada Gambar 2.

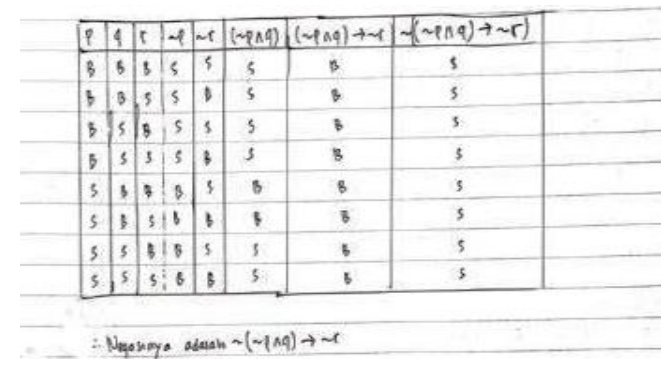

Gambar 2. Hasil S1 pada nomor 1

Berdasarkan Gambar 2 terlihat bahwa belum dapat menemukan pola dari soal yang diberikan. S1 hanya menentukan negasi dari pernyataan majemuk yang diberikan dengan hanya menambah simbol negasi $(\sim)$ dari pernyataan majemuk yang diberikan sedangkan pola atau negasi yang dimaksud harus menggunakan konsep dari negasi pernyataan majemuk ekuivalen yang pernah diajarkan.

Sedangkan berdasarkan wawancara yang dilakukan kepada subjek S1 diperoleh informasi bahwa S1 lupa bahwa negasi dari $\mathrm{p} \rightarrow \mathrm{q}$ hasilnya apa sehingga tidak menguraikan hasilnya. Sehingga dapat disimpulkan bahwa $\mathrm{S} 1$ belum memenuhi indikator 
DOI: https://doi.org/10.24127/ajpm.v10i2.3372

menemukan pola pada gejala matematis.

Hasil pekerjaan S1 untuk soal nomor 2 dapat dilihat pada Gambar 3.

\begin{tabular}{|c|c|c|c|c|c|c|}
\hline 1 & 4 & -4 & $(n-9)$ & $1+4$ & $\sim(1+a)$ & $(n-4)+\sim(1+9)$ \\
\hline 5 & 3 & 5 & 5 & 1 & 5 & $b$ \\
\hline$b$ & 5 & 5 & 6 & 5 & $b$ & $b$ \\
\hline 5 & $b$ & 5 & 5 & $b$ & 5 & $b$ \\
\hline 5 & 5 & 5 & 5 & $b$ & 5 & $b$ \\
\hline
\end{tabular}

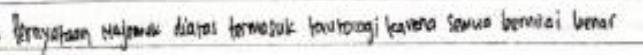

Gambar 3. Hasil S1 pada nomor 2

Berdasarkan Gambar 3 terlihat bahwa S1 dapat menyusun dugaan dalam menentukan pernyataan majemuk tersebut termasuk dalam menentukan jenis pernyataan tersebut dimana $\mathrm{S} 1$ membuat tabel kebenaran dari pernyataan majemuk. Tabel kebanaran yang disusun telah benar dan tepat sehingga ketika menentukan pernyataan majemuk tersebut ke dalam penyataan apa, S1 juga dapat menentukan dengan benar dan tepat ke dalam jenis tautologi. Selain itu, S1 juga memberikan alasan dengan benar dan tepat kenapa pernyataan tersebut termasuk dalam tautologi.

Berdasarkan wawancara yang dilakukan diperoleh informasi bahwa $\mathrm{S} 1$ sangat memahami cara membuat tabel kebenaran dimana dapat menjelaskan dengan benar ketika ditanyakan. Sehingga dapat disimpulkan bahwa S1 sudah memenuhi indikator menyusun dugaan dari pernyataan majemuk.

Hasil pekerjaan S1 untuk soal nomor 3 dapat dilihat pada Gambar 4 . Pada Gambar 4 terlihat bahwa siswa S1 telah mengerti konsep yang digunakan dalam menyelesaikan masalah yang diberikan. Hal ini terlihat S1 menentukan terlebih dahulu pernyataan yang ekuivalen dari pernyataan majemuk yang diberikan dengan konsep
Dalil de Morgan kemudian S1 memberikan bukti dari kebenaran pernyataan yang telah dibuat dengan membuat tabel kebenaran dari kedua pernyataan di setiap ruas baik ruas kiri dan ruas kanannya. Langkah selanjutnya terlihat $\mathrm{S} 1$ membandingkan hasil tabel kenearan dari ruas kiri dan ruas kanan dan menyimpulkan bahwa kedua pernyataan ekuivalen.

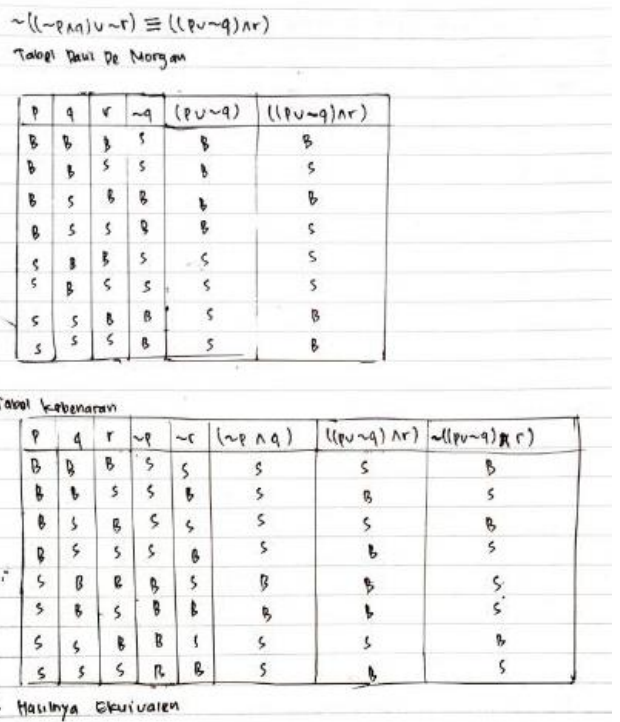

Gambar 4. Hasil S1 pada nomor 3

Dari wawancara yang dilakukan, S1 dapat menguraikan cara dalam menjawab soal serta dapat menyebutkan pernyataan yang ekuivalen dengan tepat dan benar. Berdasarkan hal tersebut maka disimpulkan bahwa S1 sudah memenuhi indikator memberikan alasan dari pernyataan majemuk.

Hasil pekerjaan S1 untuk soal nomor 4 dapat dilihat pada Gambar 5 .

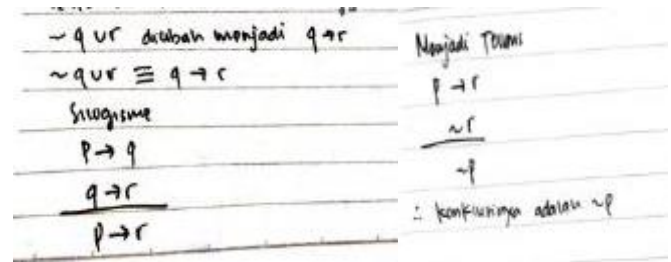

Gambar 5. Hasil S1 pada nomor 4 
Pada Gambar 5 terlihat bahwa siswa S1 mengerti konsep dari penarikan kesimpulan dimana $\mathrm{S} 1$ dapat menarik kesimpulan dari premis yang diberikan. Hal ini terlihat S1 telah dapat menentukan penarikan kesimpulan dengan benar dan tepat dimana pertama-tama S1 menentukan dulu kesimpulan dari dua premis diawal dan dapat mengubah dengan benar $\sim q \vee r$ menjadi atau ekuivalen dengan $q \rightarrow r$ sehingga dalam menentukan penarikan kesimpulan dari 2 konklusi tersebut juga benar yaitu $p \rightarrow r$. Kemudian selanjutnya hasil yang didapat ditarik kesimpulan dengan premis ketiga dan S1 juga dapat menentukan kesimpulan dengan benar berdasarkan konsep dari penerikan kesimpulan.

Wawancara yang dilakukan kepada S1 diperoleh informasi bahwa S1 memberikan penjelasan dengan benar dalam menjawab soal dimana S1 mengetahui konsep dari penarikan kesimpulan silogisme dengan mengubah terlebih dahulu salah satu premis agar sesuai dengan konsep silogisme. Dengan demikian, S1 sudah memenuhi indikator menarik kesimpulan dari suatu pernyataan.

Hasil pekerjaan S1 untuk soal nomor 5 dapat dilihat pada Gambar 6 .

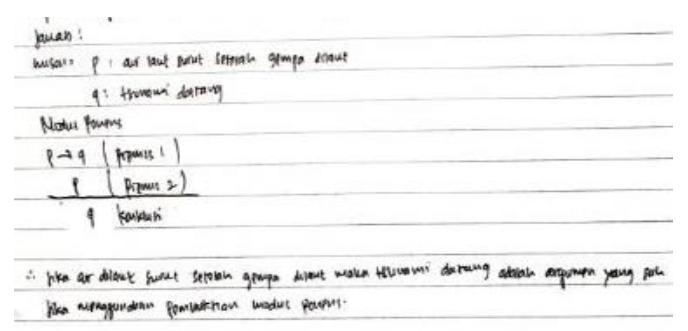

Gambar 6. Hasil S1 pada nomor 5

Pada Gambar 6 terlihat bahwa siswa S1 dapat memeriksa kesahihan soal dengan membentuk argumen tersebut menjadi sebuah pernyataan simbol logika kemudian S1 dapat menentukan bahwa argumen tersebut

termasuk ke dalam modus ponens dimana S1 memberikan jawaban dengan benar dan tepat. Hal ini terlihat bahwa S1 mengerti konsep dari suatu penarikan kesimpulan dimana dalam menentukan sah atau tidak argumen yang diberikan S1 menyatakan termasuk dalam modus ponens.

Berdasarkan wawancara yang dilakukan kepada S1 diperoleh informasi bahwa S1 memahami konsep dari penarikan kesimpulan modus ponens bahkan ketika ditanyai tentang konsep dari semua penarikan kesimpulan dan S1 menjelaskan dengan tepat dan benar. Dengan demikian, S1 sudah memenuhi indikator memeriksa kesahihan suatu argumen.

\section{Deskripsi Hasil Tes Tertulis Pada S2}

Hasil pekerjaan S2 untuk soal nomor 1 terlihat pada Gambar 7.

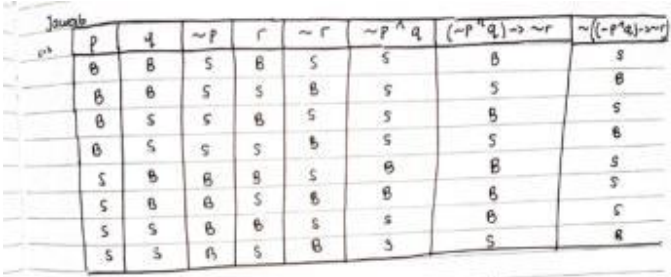

Gambar 7. Hasil S2 pada nomor 1

Pada Gambar 7, S2 tidak dapat menemukan pola pada soal yang diberikan. S2 hanya membuat tabel kebenaran dari pernyataan majemuk di soal yang diberikan namun tabel kebenaran yang dibuat juga salah dimana pada baris kedua, keempat, dan kedelapan ketika menentukan $(\sim p \wedge q) \rightarrow \sim r \quad$ yaitu $\quad \mathrm{S} \rightarrow \mathrm{B}$ seharusnya $B$ bukan $S$ begitu juga sebaliknya ketika menentukan nilai kebenaran pada baris kelima juga terjadi kesalahan dimana $\mathrm{B} \rightarrow \mathrm{S}$ seharusnya bernilai $S$ bukan bernilai B. Ketika menentukan negasinya, S2 hanya mencarinya dengan cara menentukan 
negasi dari nilai kebenran yang ditentukan sedangkan pola yang seharusnya ditentukan dengan konsep negasi yang ekuivalen tidak dilakukan oleh S2.

Berdasarkan wawancara diperoleh informasi bahwa S2 mengakui tidak memahami dalam mencari negasi dari penyataan majemuk. Sehingga dapat disimpulkan bahwa S2 belum memenuhi indikator menemukan pola pada gejala matematis.

Hasil pekerjaan S2 untuk soal nomor 2 terlihat pada Gambar 8.

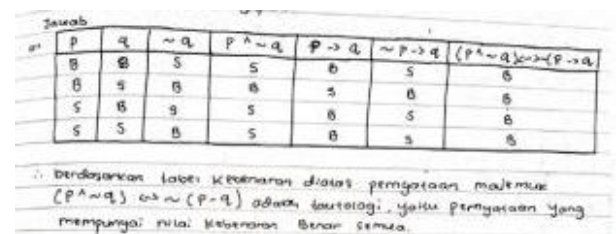

Gambar 8. Hasil S2 pada nomor 2

Pada Gambar 8 terlihat bahwa telah dapat menyusun dugaan. Langkah S2 dalam menentukan pernyataan majemuk pada soal termasuk ke dalam tautologi, kontrakdiksi atau kontingensi dengan cara membuat tabel kebenaran dari pernyataan majemuk tersebut. Tabel kebenaran dari pernyataan majemuk yang dibuat juga dibuat dengan benar dan tepat. Ketika menentukan masuk ke dalam jenis apa, S2 juga melakukan dugaan dengan benar dan tepat yaitu termasuk dalam tautologi dan memberikan alasan yang tepat.

Berdasarkan wawancara yang dilakukan diperoleh informasi bahwa S2 memahami konsep dari tautologi, kontradiksi, dan kontingensi dimana ketika diberi pertanyaan untuk menjelaskan bagaimana cara membentuk tabel kebenaran, S1 juga memberikan penjelasan dengan sangat detail dan tepat. Dengan demikian, S2 sudah sudah dapat menyusun dugaan dari pernyataan majemuk.
Hasil pekerjaan S2 untuk soal nomor 3 terlihat pada Gambar 9.

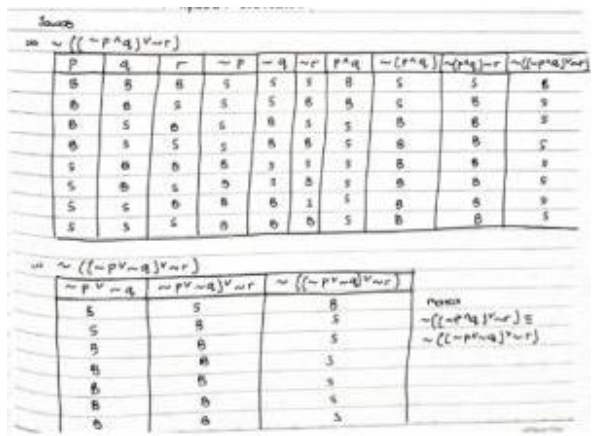

Gambar 9. Hasil S2 pada nomor 3

S2 tidak dapat memberikan alasan atau bukti dengan benar. Hal ini terlihat bahwa S2 tidak mengerti konsep dari Dalil de Morgan. Walaupun S2 menunjukkan pada tabel kebenaran dari kedua pernyataan majemuk yang ekuivalen tersebut sama atau ekuivalen tetapi hasil yang ditunjukkan salah dikarenakan S2 salah dalam membuat tabel kebenaran. Konsep Dalil de Morgan yang dituliskan S2 dengan jawaban $\sim((\sim p \wedge q) \vee \sim r) \equiv$ $\sim((\sim p \vee \sim q) \vee \sim r)$ salah dimana konsep dari Dalil de Morgan $\sim(\sim a \wedge \sim b) \equiv$ $a \vee b$.

Dari wawancara yang dilakukan, S2 tidak dapat menguraikan hasil pernyataan yang ekuivalen dari $\sim(\sim p \wedge \sim q)$ dengan benar. Berdasarkan hal tersebut maka disimpulkan bahwa $\mathrm{S} 2$ belum memenuhi indikator memberikan alasan dari pernyataan majemuk.

Hasil pekerjaan S2 untuk soal nomor 4 terlihat pada Gambar 10.

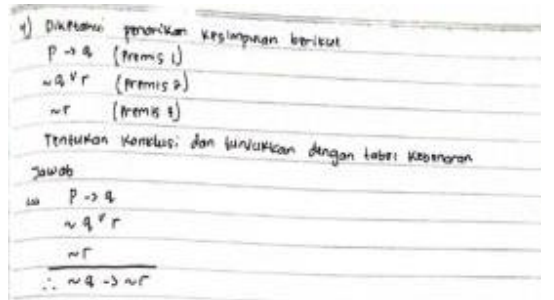

Gambar 10. Hasil S2 pada nomor 4 
S2 tidak dapat menarik kesimpulan dari premis-premis yang diberikan. Hal ini terlihat bahwa S2 tidak memahami konsep dimana S2 langsung menarik kesimpulan dari ketiga premis yang diberikan padahal dalam penarikan kesimpulan hanya dapat dilakukan dari dua buah premis saja baru seletah hasil yang didapat dari kedua premis dilakukan penarikan kesimpulan dengan premis ketiga.

Wawancara yang dilakukan kepada S2 diperoleh informasi bahwa tidak memahami konsep penarikan kesimpulan dari 3 buah premis. Dengan demikian, $\mathrm{S} 2$ belum memenuhi indikator menarik kesimpulan dari suatu pernyataan.

Hasil pekerjaan S2 untuk soal nomor 5 terlihat pada Gambar 11.

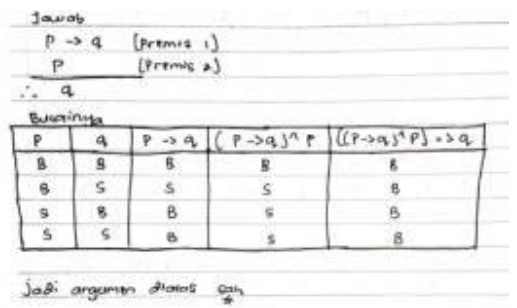

Gambar 11. Hasil S2 pada nomor 5

S2 dapat memeriksa kesahihan dari argumen yang diberikan pada soal dengan benar. Langkah S2 dalam memeriksa kesahihan argumen yang diberikan dengan mengubah pernyataan dengan permisalan simbol dari pernyataan lalu memeriksa kebenaran atau kesahihan dengan membuat tabel kebenaran dari kedua premis serta konklusi. Dari tabel kebenaran yang dibuat S2 telah dilakukan dengan benar dan S2 juga benar menyatakan bahwa argumen yang diberikan pada soal sah dikarenakan S2 mengerti konsep dari kesahihan argumen ketika hasil akhirnya B semua maka argumen sah.

Berdasarkan wawancara yang dilakukan kepada S2 diperoleh informasi bahwa S2 memahami konsep dari penarikan kesimpulan modus ponens dan cara membuktikan bahwa argumen itu sah atau tidak. Dengan demikian, S2 sudah memenuhi indikator memeriksa kesahihan suatu argumen.

\section{Deskripsi Hasil Tes Tertulis Pada S3}

Hasil pekerjaan S3 untuk soal nomor 1 terlihat pada Gambar 12.

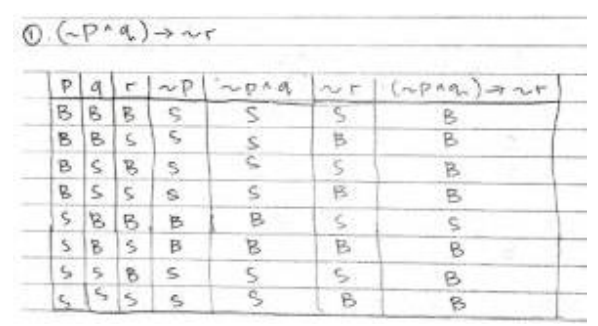

Gambar 12. Hasil S3 pada nomor 1

S3 tidak dapat menemukan negasi dari pernyataan majemuk yang diberikan pada soal. Hal ini terlihat bahwa S3 hanya membentuk tabel kebenaran dari pernyataan majemuk yang diberikan.

Berdasarkan wawancara yang dilakukan kepada subjek S3 diperoleh informasi bahwa S3 tidak memahami cara dalam mencari negasi dari suatu pernyataan. Sehingga dapat disimpulkan bahwa S3 tidak dapat memenuhi indikator menemukan pola pada gejala matematis.

Hasil pekerjaan S3 untuk soal nomor 2 terlihat pada Gambar 13.

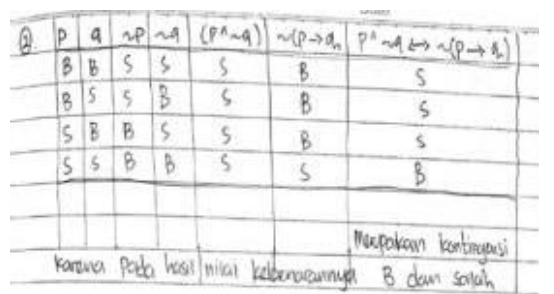

Gambar 13. Hasil S3 pada nomor 2

Berdasarkan Gambar 13, S3 tidak dapat menyusun dugaan. Hal ini terlihat 
S3 tidak dapat membuat tabel kebenaran dengan benar dan tepat dimana S3 kurang membuat satu kolom untuk menentukan hasil akhir dari nilai kebenaran pernyataan majemuk pada soal yaitu S3 tidak membentuk tabel nilai kebenaran $p \rightarrow q$ tetapi S3 langsung mencari nilai kebenaran $\sim(p \rightarrow q)$ dan nilai kebenaran yang dibentuk dari $\sim(p \rightarrow q)$ juga salah. Selain itu, S3 juga salah dalam membentuk nilai kebenran dari $p \wedge \sim q$ pada baris kedua seharusnya bernilai $\mathrm{B}$ bukan bernilai $S$. Karena nilai kebenaran dari $p \wedge \sim q$ dan $\sim(p \rightarrow q)$ yang dibentuk oleh S3 salah maka maka hasil akhir nilai kebenaran dari pernyataan majemuk pada soal juga terjadi kesalahan dalam membentuknya.

Berdasarkan wawancara yang dilakukan diperoleh informasi bahwa S3 tidak dapat menjelaskan dengan benar terkait nilai kebenaran dari $\sim(p \rightarrow q)$. S3 mengakui keliru dalam menentukan nilai kebenaran dari suatu pernyataan majemuk. Sehingga dapat disimpulkan bahwa S3 tidak dapat memenuhi indikator menyusun dugaan dari pernyataan majemuk.

Hasil pekerjaan S3 untuk soal nomor 3 terlihat pada Gambar 14.

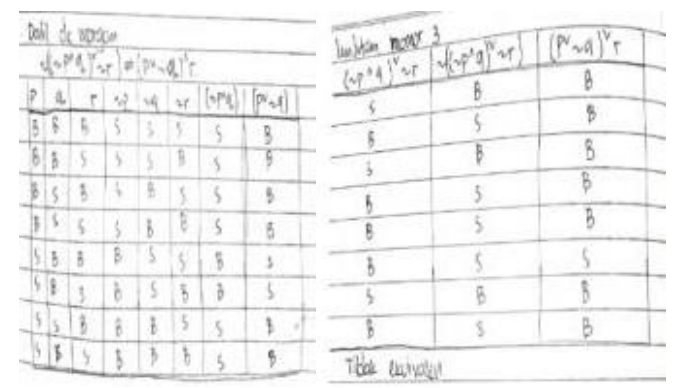

Gambar 14. Hasil S3 pada nomor 3

Pada Gambar 14, S3 mengerti konsep dari Dalil De Morgan dimana dalam menentukan pernyataan yang ekuivalen dengan pernyataan majemuk pada soal dilakukan S3 dengan benar.
Namun ketika memberikan bukti atau alasan dengan membentuk tabel kebenaran dari masing-masing pernyataan majemuk, S3 mengalami kekeliruan di tanda pernyataan majemuk yang dibentuk dimana S3 mencari $(p \vee \sim q) \vee r$ seharusnya sesuai dengan negasi yang dibentuk diawal S3 mencari atau membentuk nilai kebenaran dari $(p \vee \sim q) \wedge r$ sehingga ketika menentukan apakah ekuivalen atau tidak juga mengalami kesalahan dikarenakan salah dalam membentuk pernyataan majemuk.

Dari wawancara yang dilakukan, S3 memahami konsep dari mencari nilai kebenaran dari suatu pernyataan dimana S3 dapat mengklasifikasi jawaban dengan benar ketika disuruh mengulang mencari jawaban dari $(p \vee \sim q) \wedge r$. Berdasarkan hal tersebut maka disimpulkan bahwa S3 sudah memenuhi indikator memberikan alasan dari pernyataan majemuk.

Hasil pekerjaan S3 untuk soal nomor 4 terlihat pada Gambar 15.

(4). $\frac{P \rightarrow 9}{q^{v} r}$ (Premis 1)
$\frac{\sim}{\sim r} \quad$ (Premis 2)

Gambar 15. Hasil S3 pada nomor 4

Pada Gambar 15, S3 tidak dapat membentuk konklusi dari soal yang diberikan. S3 tidak ada membentuk hasil konklusi dari soal yang diberikan.

Wawancara yang dilakukan kepada S3 diperoleh informasi bahwa S3 tidak memahami konsep dari penarikan kesimpulan dari 3 buah premis. Dengan demikian, S3 belum memenuhi indikator menarik kesimpulan dari suatu pernyataan.

Hasil pekerjaan S3 untuk soal nomor 5 terlihat pada Gambar 16. 


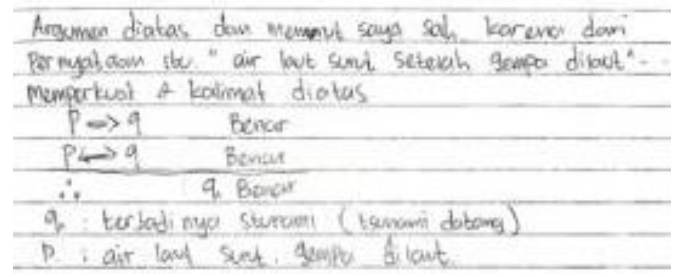

Gambar 16. Hasil S3 pada nomor 5

Pada Gambar 16, S3 tidak dapat memeriksa kesahihan argumen yang diberikan. Hal ini terlihat bahwa S3 hanya membentuk pernyataan atau argumen yang diberikan pada soal dengan permisalan simbol logika saja.

Berdasarkan wawancara yang dilakukan kepada S3 diperoleh informasi bahwa S3 tidak dapat menjelaskan kembali jawaban yang diberikan dimana S3 mengakui dalam menjawab soal hanya menerka saja. Dengan demikian, S3 tidak dapat memenuhi indikator memeriksa kesahihan suatu argumen.

Berdasarkan hasil analisis yang dilakukan terhadap hasil pekerjaan mahasiswa dan wawancara yang dilakukan diperoleh bahwa mahasiswa dengan kreativitas belajar tinggi mememenuhi empat indikator yaitu menyusun dugaan, memberikan alasan terhadap kebenaran suatu pernyataan, menarik kesimpulan dari suatu pernyataan, dan memeriksa kesahihan suatu argumen namun belum memenuhi indikator menemukan pola dari gejala matematis. Mahasiswa dengan kreativitas belajar sedang hanya memenuhi dua indikator yaitu menyusun dugaan dan memeriksa kesahihan suatu argumen. Hal ini terjadi dikarenakan mahasiswa dengan kreativitas sedang tidak menguasai konsep dari mencari negasi dari suatu pernyataan sedangkan pada indikator memberikan alasan terhadap kebenaran suatu pernyataan dan menemukan pola memuat soal yang mencari negasi dari suatu pernyataan. Selain itu, mahasiswa dengan kreativitas sedang tidak mengerti cara menarik kesimpulan dengan 3 buah premis menyebabkan penarikan kesimpulan tidak dapat dilakukan.

Mahasiswa dengan kreativitas belajar rendah hanya memenuhi satu indikator yaitu memberikan alasan atau bukti terhadap suatu pernyataan. Mahasiswa dengan kreativitas rendah tidak menguasai konsep dari logika matematika sehingga kesulitan dalam memahami masalah dikarenakan kurangnya informasi yang diberikan (Hanifah, 2016; Hidayah, 2016; Irawati, 2015). Hal ini menunjukkan bahwa kreativitas sangat berkaitan dengan penalaran mahasiswa dimana mahasiswa yang memiliki kreativitas belajar tinggi dapat memenuhi indikator yang lebih banyak dibandingkan dengan kreativitas sedang dan rendah. Selain itu, mahasiswa dengan kreativitas tinggi dapat mengaitkan pengetahuan yang dimilikinya terhadap hal-hal baru yang mereka temukan. Selain itu, penelitian (Amalia, 2015; Purnamasari, WA, \& Hadiyah, 2013) juga mendukung bahwa siswa dengan kreativitas belajar tinggi memiliki pemahaman dan hasil belajar yang lebih baik daripada siswa dengan kreativitas belajar rendah.

Kreativitas belajar memberikan dampak dari kemampuan penalaran adaptif. Dari hasil penelitian menunjukkan bahwa mahasiswa dengan kreativitas belajar tinggi dapat memenuhi indikator dari kemampuan penalaran adaptif yang lebih banyak dibandingkan dengan mahasiswa dengan kreativitas belajar sedang dan rendah. Hal ini menunjukkan bahwa kreativitas memberikan pengaruh terhadap kemampuan penalaran mahasiswa terutama kemampuan penalaran adaptif. Hal ini sejalan dengan pernyataan (Katagiri, 2004) 
menyebutkan bahwa kreativitas siswa dalam belajar matematika berkaitan dengan keaktifan siswa, pemenuhan kebutuhan akademik, penalaran matematika dan strategi belajar matematika.

\section{KESIMPULAN DAN SARAN}

Berdasarkan hasil dan pembahasan, maka diperoleh kesimpulan bahwa mahasiswa dengan kreativitas belajar tinggi memenuhi indikator menyusun dugaan, memberikan alasan terhadap kebenaran suatu pernyataan, menarik kesimpulan dari suatu pernyataan, dan memeriksa kesahihan suatu argumen namun belum memenuhi indikator menemukan pola dari gejala matematis, mahasiswa dengan kreativitas belajar sedang hanya memenuhi indikator menyusun dugaan dan memeriksa kesahihan suatu argumen dan mahasiswa dengan kreativitas belajar rendah hanya memenuhi indikator memberikan alasan atau bukti terhadap suatu pernyataan.

Berdasarkan hasil penelitian maka disarankan kepada mahasiswa hendaknya lebih banyak berlatih secara mandiri mengerjakan soal terutama soal yang berhubungan dengan penalaran. Sebelum mengerjakan soal sebaiknya mahasiswa menguasai atau memahami konsep dari logika matematika terlebih dahulu agar kemampuan penalaran mahasiswa dapat dilakukan dengan benar dan tepat. Selain itu, untuk penelitian selanjutnya dapat menerapkan suatu model pembelajaran dimana dengan memfokuskan kepada peningkatan kemampuan penalaran adaptif.

\section{UCAPAN TERIMA KASIH}

Terima kasih diucapkan kepada KEMENRISTEKDIKTI dana hibah Penelitian Dosen Pemula tahun anggaran 2019 serta IKIP PGRI Pontianak sebagai mitra dalam kegiatan penelitian.

\section{DAFTAR PUSTAKA}

Afifian, H. P., \& Setyaningsih, E. (2019). Deskripsi Kemampuan Penalaran Adaftif Siswa di SMP Negeri 5 Purwokerto Ditinjau dari Keaktifan Belajar Siswa. Journal of Mathematics Education, 5(2), 34-39.

Amalia, N. (2015). Pengaruh Teknik Pembelajaran dan Kreativitas Belajar Siswa Terhadap Hasil Belajar Matematika. JKPM, 01(01), 31-45.

Bernard, M. (2015). Meningkatkan

Kemampuan Komunikasi Dan Penalaran Serta Disposisi Matematik Siswa Smk Dengan Pendekatan Kontekstual Melalui Game Adobe Flash Cs 4.0. Infinity Journal, 4(2), 197. https://doi.org/10.22460/infinity.v4 i2.84

Budiarti, I., \& Jabar, A. (2016). Pengaruh gaya belajar terhadap hasil belajar matematika siswa kelas VIII SMPN 2 Banjarmasin tahun ajaran 2015/2016. Math Didactic: Jurnal Pendidikan Matematika, 2(3), 142-147. https://doi.org/10.33654/math.v2i3 .42

Hanifah, A. I. (2016). Analisis Kesalahan Siswa Dilihat dari Skema Dalam Menyelesaikan Masalah Matematika. Jurnal Reforma, 4(1), 30-41. https://doi.org/10.30736/rfma.v4i1. 9

Herdiman, I. (2017). Penerapan Pendekatan Open-Ended Untuk Meningkatkan Penalaran Matematik Siswa Smp. JES-MAT (Jurnal Edukasi Dan Sains 
Matematika), 3(2), 195-204. https://doi.org/10.25134/jesmat.v3i2.691

Hidayah, S. (2016). Analisis kesalahan siswa dalam menyelesaikan soal cerita SPLDV berdasarkan langkah penyelesaian Polya. Jurnal Pendidikan, 1(2), 182-190.

Indriani, T., Hartoyo, A., \& Astuti, D. (2017). Kemampuan Penalaran Adaptif Siswa Dalam Memecahkan Masalah Kelas VIII SMP Pontianak. Jurnal Pendidikan Dan Pembelajaran Khatulistiwa, 6(2), 1-12. Retrieved from http://jurnal.untan.ac.id/index.php/j pdpb/article/view/18396/15527

Irawati, S. (2015). Analisis Kesalahan Mahasiswa Calon Guru Matematika dalam Memecahkan Masalah Program Linier. Sigma, 1(1), 29-34.

Kasmer, L., \& Kim, O.-K. (2011). Using Prediction to Promote Mathematical Understanding and Reasoning. School Science and Mathematics, 111(1), 20-33. https://doi.org/10.1111/j.19498594.2010.00056.x

Katagiri, S. (2004). Mathematical Thinking and How to Teach It. In Progress report of the APEC project: "Colaborative Studies on Innovation for Teaching and Learning Mathematics in Diferent Cultures (II) - Lesson Study focusing on Mathematical Thinking." Tokyo: CRICED, University of Tsukuba.

Kilpatrick, J., \& Swafford, J. (2001). Adding It Up Helping Children Learn Mathematics. Washington DC: National Academiy Press.

Lestari, I., \& Andinny, Y. (2020). Kemampuan Penalaran Matematika melalui Model Pembelajaran Metaphorical
Thinking Ditinjau dari Disposisi Matematis. Jurnal Elemen, 6(1), $1-12$.

https://doi.org/10.29408/jel.v6i1.1 179

Mirati, L. (2013). Analisis Kesulitan Belajar Matematika Pada Topik Logika Pada Siswa SMK Muhammadiyah 3 Klaten Utara. Journal of Chemical Information and Modeling, 53(9), 1689-1699.

Novianti, D. E. (2015). Analisis Kesalahan Dalam Mengerjakan Soal Materi Logika Matematika Mahasiswa Prodi Pendidikan Matematika IKIP PGRI Bojonegoro. Jurnal Pendidikan Dan Pembelajaran Matematika, 1(1), 24-30.

Oktaviana, D., \& Haryadi, R. (2020). Kemampuan Penalaran Adaptif Melalui Model Reciprocal Teaching pada Logika Matematika dan Himpunan. SAP (Susunan Artikel Pendidikan), 5(2), 124130.

Ponte, J. P., Mata-Pereira, J., \& Henriques, A. C. (2012). O raciocínio matemático nos alunos do Ensino Básico e do Ensino Superior. Praxis Educativa, 7(2), 355-377.

https://doi.org/10.5212/praxeduc.v. $7 \mathrm{i} 2.0003$

Purnamasari, L., WA, S., \& Hadiyah. (2013). Pengaruh Model Savi Terhadap Pemahaman Konsep Pesawat Sederhana Ditinjau Dari Kreativitas Belajar. Jurnal Mahasiswa PGSD UNS, 1(5), 1-6.

Putra, R. W. Y., \& Sari, L. (2016). Pembelajaran Matematika Dengan Metode Accelerated Learning Untuk Meningkatkan Kemampuan Penalaran Adaptif Siswa SMP. Jurnal Pendidikan Matematika, 7(2), 211-220. 
DOI: https://doi.org/10.24127/ajpm.v10i2.3372

Rosnawati, R. (2013). Kemampuan Penalaran Matematis Siswa SMP Indonesia pada TIMSS 2011. Prosiding Seminar Nasional Penelitian, Pendidikan Dan Penerapan MIPA, 1-6. Retrieved from

http://staffnew.uny.ac.id/upload/13 2001808/penelitian/Makalah+Sem nas $+2013+a n+$ R+Rosnawati+FMI PA+UNY.pdf

Siagian, R. E. F., \& Nurfitriyanti, M. (2015). Metode Pembelajaran Inquiry dan Pengaruhnya terhadap Hasil Belajar Matematika ditinjau dari Kreativitas Belajar. Formatif: Jurnal Ilmiah Pendidikan MIPA, 2(1), 35-44. https://doi.org/10.30998/formatif.v $2 \mathrm{i} 1.85$

Widjajanti, D. B. (2011). Mengembangkan Kecakapan Matematis Mahasiswa Calon Guru Matematika. Prosiding Seminar Nasional Penelitian, Pendidikan Dan Penerapan MIPA, 151-158.

Zulkarnaen, R. (2017). Penerapan Pendekatan Realistik Berbantuan Ict Terhadap Kemampuan Penalaran Matematis Siswa Kelas Vii. Euclid, 3(2), 578-587. https://doi.org/10.33603/e.v3i2.334 